\title{
Gum arabic collection in northern Kenya: unexploited resources, underdeveloped markets
}

\author{
Wytse Vellema (1), Gaudiose Mujawamariya (2), \\ Marijke D'Haese (1) \\ (I) Department of Agricultural Economics, Ghent University, Belgium \\ (2) Africa Rice, Dar-es-Salaam, Tanzania
}

\begin{abstract}
Gum arabic is a resin collected from several types of Acacia tree growing most densely in arid and semi-arid lands in East Africa and the Sahel. Kenya is particularly well endowed with gum-yielding trees but exports only small amounts of gum.

Methodology: A combination of descriptive livelihood and value chain analysis was used to gain insight into the socio-economic characteristics of collectors and the role of gum arabic in their livelihood.

Results: The degree of poverty encountered is considerable with most collectors barely able to maintain a subsistence level. Marketed quantities of gum arabic are low, collection practices are rudimentary, and the market is severely underdeveloped.

Conclusion: Thin markets, evidenced by a lack of specialised traders and the infrequency of their visits, removes incentives for increasing the quantity and quality of marketed gum arabic. Only when this situation changes will collectors be motivated to improve their current collecting and marketing practices, for which there is ample scope.
\end{abstract}

Key words: gum arabic, Kenya, poverty, market development, non-timber forest products

\section{Introduction}

Gum arabic is the natural exudate of several subspecies of trees and shrubs of the Acacia genus (Nishinari \& Doi, 1993). It has a wide range of uses in food, pharmaceuticals, printing, ceramics, and textile industries where it functions as an emulsifier, stabilizer, emulsifier, flavouring agent, thickener, or coating agent. (Anderson \& Weiping, I992; Cunningham et al., 2008; ICRAF, I992). The lack of a viable synthetic alternative creates a large and growing international demand (Van Dalen, 2006). Gum producing trees only naturally occur in arid and semi-arid lands, almost exclusively in sub-Saharan Africa (Islam, Phillips, Sljivo, Snowden, \& Williams, I997; White, I983), and because most demand comes from industrialised countries, almost all gum arabic is internationally traded. 
Early records indicate that international trade in gum arabic was already taking place over five thousand years ago, when the ancient Egyptians used gum arabic in paint and for the wrappings used to embalm mummies (Whistler \& BeMiller, I993). Trading volume increased quickly during colonial times (Awouda, I988), and became a vital source of income for exporting countries such as Senegal (Webb, 1985). Currently Sudan, Chad, and Nigeria are the main exporting countries (ITC, 2009).

Export statistics in value terms underestimate the importance of gum arabic in generating livelihoods. Whereas mineral sectors such as oil are relatively capital intensive, gum arabic is a labour intensive product which generates employment for large numbers of people. Given that most gum is collected from arid and semi-arid zones that have very low agricultural potential, it provides a welcome alternative source of income in such areas.

Kenya is richly endowed with Acacia trees. It is at the crossroads of two gum arabic belts, one running just south of the Sahel, the other along the east coast of Africa (Raddad, Salih, Fadl, Kaarakka, \& Luukkanen, 2005). Nearly 80\% of the country's area contains trees that produce gum arabic (Beentje, I994; Maundu, Ngugu, \& Kasuye, I999), most of which are of the species Acacia senegal var. kerensis (Booth \& Wickens, I988). However, Kenya exports only small amounts of gum arabic.

As a first step in trying to explain this apparent paradox, in this article we take a closer look at the people involved in its collection. More specifically, we look at the socioeconomic characteristics of involved households and the ways they collect and market gum arabic. In 2009, data was collected on the socio-economics of 218 gum-collecting households in Kenya and their collection and marketing practices. This information was used to analyse the role of gum arabic in the livelihoods of households involved in its collection and the activities performed by these households as a function of the local value chain. The almost complete absence of knowledge on these issues gives this research an exploratory character, with the aim of assisting efforts to more accurately target future policy and research.

\section{Data and methods}

Kenya is a geographically diverse country on the equator in the East of Africa. It is bordered by South Sudan and Ethiopia to the north, Somalia and the Indian Ocean to the east, Tanzania to the south, and Uganda to the west. Elevation increases from the coast to the central highlands, which are bisected by the rift valley. The climate varies from tropical on the coast to temperate in the highlands. Almost $80 \%$ of the country is covered in drylands, where trees producing gum arabic are found in abundance (Beentje, I994; Maundu et al., 1999). In Kenya, gum is collected from both Acacia senegal and A. seyal. This paper is concerned only with gum arabic collected from Acacia senegal. Four varieties of Acacia senegal produce gum arabic: A. senegal var. senegal, var. kerensis, var. rostrata, and var. leiorhachis (Brenan, I983; Fagg \& Allison, 2004). Of these, A. senegal var. Kerensisis, the most commonly occurring species in Kenya, forms the basis of the international export market (Booth \& Wickens, I988). Gum arabic is only collected outside of the rainy seasons, 
of which there are two; the long rains occur from March-June and the short rains from October-December. Gum is naturally exuded during both dry seasons, although gum production is generally higher during the large dry season following the long rains.

Little is known about the density in which gum arabic producing tree varieties naturally occur in different parts of Kenya. Olang (I984) was the first to make a vegetation map of Turkana district. He distinguished eight vegetation types, only one of which was specifically mentioned to contain Acacia senegal. Unfortunately, no mention is made of stocking densities. Almost a decade later in the same region, Coughenour and Ellis (I993) found Acacia senegal to be the dominant species on rocky sites with a sloping topography. This more frequent occurrence of A.senegal on hilly sites is corroborated by Chikamai, Hall, and Banks (I995) in a study specifically aimed at establishing its stocking density in Turkana, Isiolo and Marsabit district. However, in their study only sites known or expected to contain A. senegal were included, making it impossible to extrapolate average stocking densities for the entire region from their results. Given this lack of reliable density information, regions selected for this research were those where gum arabic was known to be actively collected and marketed: Mandera, Marsabit, Turkana and Samburu Counties (Chikamai \& Odera, 2002). These counties are amongst the poorest in Kenya. An overview of several welfare indicators are given in Table I. The severity of the poverty in the gum regions is immediately clear: illiteracy rates are higher, more children are underweight, and incomes and indices of human development are substantially below the country average.

\begin{tabular}{l|c|c|c|c|c} 
County & Mandera & Marsabit & Turkana & Samburu & Country \\
\hline Population (thousands) & 559.9 & I5I.I & $445 . \mathrm{I}$ & II2.0 & I9,I92.4 \\
\hline Illiteracy (\%) & 86.7 & $80 . \mathrm{I}$ & $83 . \mathrm{I}$ & 73.0 & 28.6 \\
\hline Children underweight (\%) & $4 \mathrm{I} .2$ & 32.3 & 34.5 & 44.0 & 20.9 \\
\hline Annual income (USD, PPP) & 465 & 560 & 383 & $5 \mathrm{I} 7$ & I,436 \\
\hline Human Development Index & 0.3592 & 0.3829 & $0.333 \mathrm{I}$ & $0.4 \mathrm{II} 8$ & 0.5608
\end{tabular}

Table 1: General characteristics ofgum arabic regions in Kenya.

Source: Kenya National Bureau of Statistics, Kenya National Human Development Report 2009. Note: Annual income concerns 2009 and is reported in United States dollars (USD) based on purchasing power parity (PPP).

There are no maps available containing the location of all or even most villages in the region. This lack of information on the location of villages is partly because almost all tribes in the region are nomadic or semi-nomadic, regularly migrating with their households or even entire villages (Dyson-Hudson \& Dyson-Hudson, I980; Spencer, 2004). Therefore, villages were selected by establishing whether gum was selected in a particular region, and subsequently taking the first forked road encountered. In this way, 20 villages at different distances from the main road were selected for inclusion in the survey (Figure I). Selected villages were spread relatively evenly across the gum regions. A full list containing the names of included villages is provided in the appendix. 


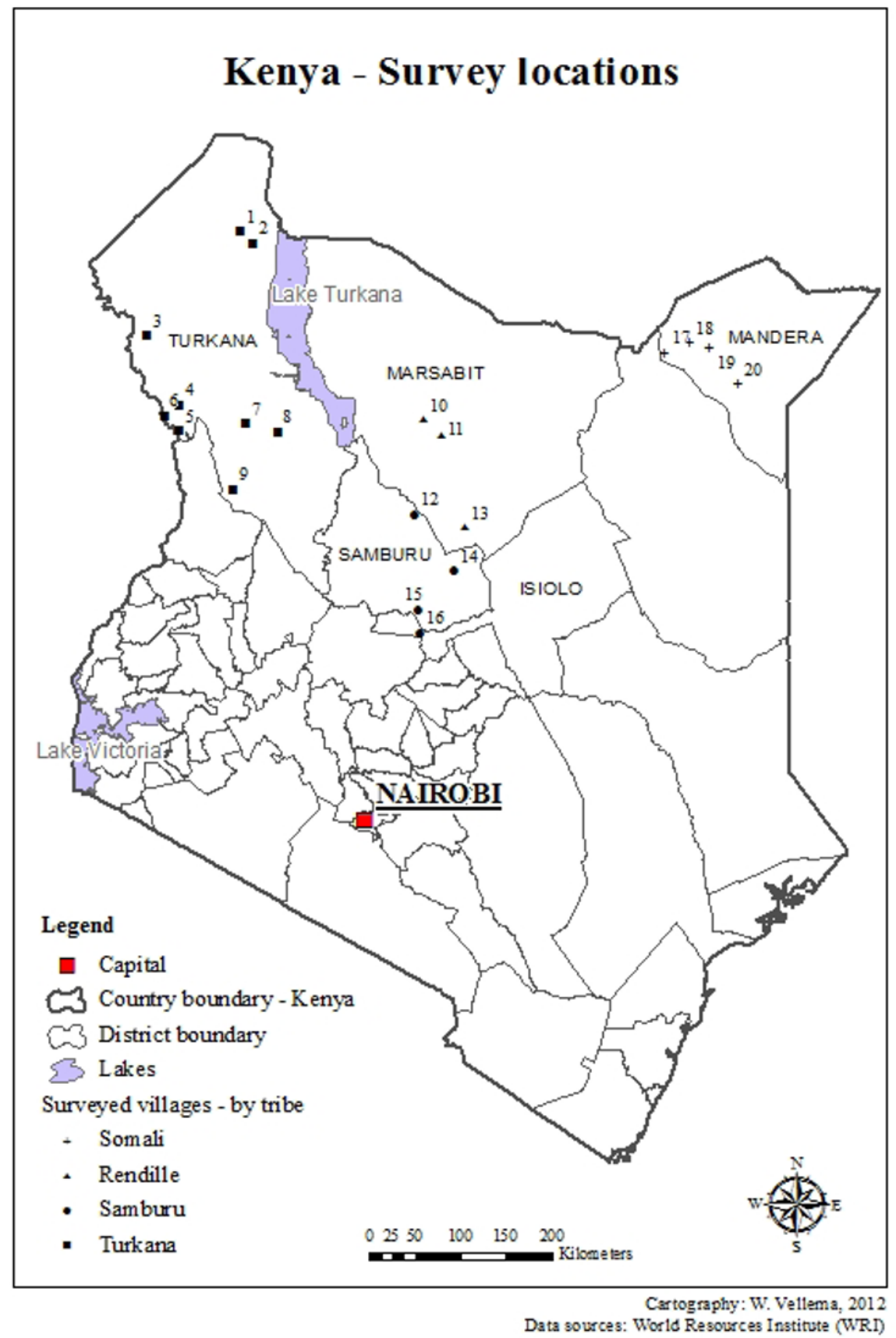

Figure 1: Location of surveyed villages 
Data collection took place in August and September 2009 as part of the ACACIAGUM project using a pre-tested semi-structured questionnaire. Individual collectors were interviewed, and asked for information on their household, the most recent harvest season, the preceding harvest season, and their habits regarding gum collection and marketing. As all information was obtained by recall, especially data on quantities and prices of gum of the preceding season might be somewhat inaccurate. Therefore, these variables were aggregated to yearly quantities and average prices. A total of $2 \mathrm{I} 8$ collectors were interviewed, one per household, with a maximum of 2I collectors per village. The dataset is unique in its focus on gum arabic collectors and the breadth of its scope and can provide valuable insight into the socio-economics of the people involved in gum collection, as well as their collection and marketing practices.

The framework used to structure the analysis is depicted in figure 2. Gum arabic collection was considered to be a livelihood strategy in the context of the sustainable livelihood framework formalized by Scoones (I998). In order to understand the importance of gum arabic for households involved in its collection,the characteristics of collecting households were first described in detail. Particular attention was paid to household composition, socio-economic position, and education. Second, the set of activities constituting the livelihoods of collecting households was described. Third, the role of gum arabic collection in the household livelihood portfolio was considered, specifically at its relative importance vis-à-vis other activities. 


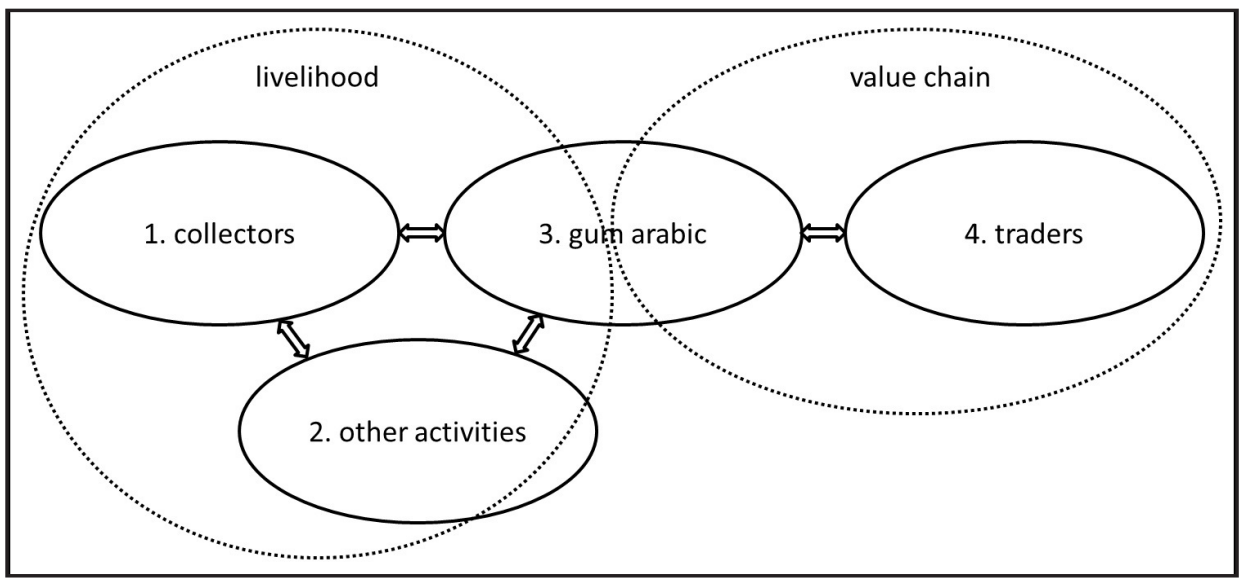

Figure 2: Framework for analysis

The role of gum arabic collection was also analysed as a function of its position in the value chain for gum arabic. Only the activities performed at the base of the value chain were considered, thus excluding long-distance transport and processing. In this part of the analysis, the focus was first on the activities performed by or available to collectors. Because these activities are influenced by the organisation of subsequent links in the value chain, the link between collectors and traders was subsequently described, and its influence on collection decisions discussed.

\section{Results}

\section{Collector characteristics}

The average age of the collectors was 36.9 years. A total number of 148 interviewed collectors were female, representing $67.9 \%$ of the sample. Most collectors were married $(89.4 \%)$ although several singles and widows were also interviewed. Out of the 23 singles and widows interviewed, only 9 were living alone, the others were members of larger households. The average household size was 6.9 , of which 4.3 were children. Only 22 interviewed individuals, slightly over 10\% of the sample, had received any educationv implying that $90 \%$ of interviewed collectors were illiterate. Of those who had attended school, only 3 attended secondary school; and of the individuals who had not progressed beyond primary education, only 4 had managed to finish. Therefore, especially given the absence of books and writing materials, functional literacy rates in our sample are unlikely to exceed $5 \%$ (Table 2). 


\begin{tabular}{l|c|c|c|c} 
Characteristic & Average & Min & Max & SD \\
\hline Age & 36.9 & I5 & 80 & I2.0 \\
\hline \% female collectors & $67.9 \%$ & - & - & - \\
\hline$\%$ married & $89.4 \%$ & - & - & - \\
\hline Household size & 6.9 & I & 20 & 3.I \\
\hline Number of children & 4.3 & 0 & I4 & 2.5 \\
\hline \% formal education & I0.1\% & - & - & - \\
\hline Years of education & 0.6 & 0 & I2 & 2.0
\end{tabular}

Table 2: Household characteristics ( $n=218)$. Source: own data.

\section{Livelihood activities}

The main source of income for interviewed households was pastoralism, followed by gum arabic and wood products (Table 3). The predominance of pastoralism is common in arid and semi-arid regions all over Africa, and well documented for Kenya (Gulliver, I95I; Lewis, I999; Spencer, I973, 2004). However, it is perhaps surprising that so many gum collectors named the activity as their primary source of income given that loss of livestock has been found to be the most commonly cited reason for households to become involved in gum arabic collection in southern Ethiopia - an area similar and close to our study area, Woldeamanuel, Arts, Lemenih, and Bongers (20II). At the beginning of the interview respondents were informed of its objective and hence households might have overstated the importance of gum arabic for their income, an effect known as social desirability bias (Grimm, 20I0). For the same reason woodcutting and charcoal making are likely to have been under reported.

\begin{tabular}{l|c|c|c|c} 
& Primary & & Secondary & \\
\hline Income source & (n) & $\%$ & (n) & $\%$ \\
\hline Commerce & 6 & $3 \%$ & I0 & $5 \%$ \\
\hline Agriculture & 0 & $0 \%$ & 0 & $0 \%$ \\
\hline Pastoralism & $\mathrm{I} 66$ & $76 \%$ & 32 & $\mathrm{I} 5 \%$ \\
\hline Wages & $\mathrm{I}$ & $0 \%$ & 5 & $2 \%$ \\
\hline Wood products & 2 & $\mathrm{I} \%$ & 78 & $36 \%$ \\
\hline Gum arabic & 34 & $\mathrm{I} 6 \%$ & $7 \mathrm{I}$ & $33 \%$ \\
\hline Remittances & 0 & $0 \%$ & 0 & $0 \%$ \\
\hline Relief & 9 & $4 \%$ & $2 \mathrm{I}$ & $\mathrm{I} \%$ \\
\hline Other non-wood products & 0 & $0 \%$ & $\mathrm{I}$ & $0 \%$ \\
\hline Total & $2 \mathrm{I} 8$ & $\mathrm{I} \% \%$ & $2 \mathrm{I} 8$ & $\mathrm{I00} \%$
\end{tabular}

Table 3: Main income sources ( $n=218)$. Source: own data. 
Relief, commerce, and wage labour was not common, and none of the interviewed collectors were involved in agriculture. Relief was widespread in the region and has taken on a structural character since the I980s. Many families in the region were structurally dependent on food aid and cash for work schemes in order to make a living. In I999, half the population of Turkana province were estimated to have received food aid, a situation which seemed unlikely to change in the near future (Lind, 2005). Several people also reported income from commerce/small trade. Most of them owned shops so small that inventories could usually be carried by a single person. Wage jobs were rare and much sought after. None of the respondents depended on agriculture, which is surprising given the ongoing sedentarisation process (Roth \& Fratkin, 2005; Smith, 2005). Perhaps agriculture was not feasible in the dry areas where gum-yielding tree varieties are found, which typically have poor soils with low moisture content (Chiveu, Dangasuk, Omunyin, \& Wachira, 2008). The drylands contain several varieties of gums, resins and other non-wood forest products, yet in the study area, gum arabic is the most important of these collected products because of the existing (yet limited, see below) market opportunities.

\begin{tabular}{|c|c|c|c|c|c|}
\hline & $\mathbf{n}$ & Average & Min & Max & SD \\
\hline Cattle & 77 & $4 . \mathrm{I}$ & 0 & 30 & $3 \cdot 5$ \\
\hline Sheep & I53 & I0.2 & 0 & 80 & I0.8 \\
\hline Goats & 156 & I3.I & 0 & 150 & I8.0 \\
\hline Donkeys & 80 & I. 5 & 0 & 5 & 0.9 \\
\hline Camels & 74 & 6.9 & 0 & 50 & 7.0 \\
\hline Tropical Livestock Units & I88 & $5 \cdot 9$ & 0 & 62.0 & 8.4 \\
\hline Household size $(\mathrm{AE})^{\star}$ & 216 & $3 \cdot 4$ & I & 8.4 & $\mathrm{I} \cdot 3$ \\
\hline TLU/household size (AE)^ & I86 & I. 8 & 0 & 17.0 & 2.4 \\
\hline
\end{tabular}

Table 4: Livestock ownership (heads).

Source: own data. Note: averages were taken over households owning the type of animal; minimum, maximum and standard deviations over all households. "Tropical livestock units were calculated as $1 \mathrm{TLU}=1$ cattle $=1.25 \mathrm{camel}=10 \mathrm{small}$ stock $=$ 2 donkeys. ${ }^{*} A d u l t$ equivalents, calculated as $A E=(A+\alpha K) \theta$, where $A$ refers to adults, $K$ to children and $\alpha$ and $\theta$ are weights. For low-income households, Deaton and Muelbauer (1980) and Deaton (1997) recommended setting $\alpha=0.3$ and $\theta=0.9$.

Although total household income could not be directly measured, the high dependence on pastoralism allowed the construction of an alternative income or wealth measure based on livestock holdings, first suggested by Pratt and Gwynne (1977). Livestock holdings are shown in Table 4. To be able to compare herds of different compositions, an index was required. The tropical livestock units (TLU) index developed by the Food and Agriculture Organisation of the United Nations (FAO, I972) assigns each type of animal a weight based on its metabolic weight. For northern Kenya, I TLU = I cow $=\mathrm{I} .25$ camels $=$ Io small stock $=2$ donkeys was considered appropriate $($ Dahl \& Hort, 
I976; Houerou \& Hoste, I977). Livestock owners in our sample owned on average 5.9 TLU of livestock. Pratt and Gwynne (I977) suggested 4.5 TLU per adult would generate enough income for subsistence. To convert households into an equivalent number of adults (AE) we used yet another index, suggested by Deaton and Zaidi (I999) ${ }^{\text {. }}$. Using this index, we found that the interviewed households owned on average I.9 TLU per adult equivalent household member, far below the level required for a subsistence income. In fact, only 20 households in our sample had sufficient livestock for a subsistence living and 32 households had no livestock at all, indicating most households had both low incomes and a high dependence on secondary sources of income. The low-income status of gum collectors has previously been established in gum collection areas just across the border in Ethiopia by Woldeamanuel et al. (20II). In fact, they found it was often the loss of livestock that encouraged households to start collecting gum. The relative poverty of collectors is also widely established for other NTFPs (Timko, Waeber, \& Kozak, 20Io).

\section{The role of gum arabic}

Only low levels of income were generated through the collection and subsequent sale of gum arabic, in spite of the fact that it was mentioned as the second most important source of income (Table 3). Selected gum collection variables are presented in Table 5. On average, in 2009 interviewed households made 2,084 Kenyan Shillings (KES) from gum arabic sales ${ }^{2}$. To put this level of income into perspective we can compare it to rural poverty levels set by the Kenyan government. Available information closest to time of the survey stemmed from 2006, when the rural poverty level was 1562 KES per month per adult and the rural food poverty level, the bare minimum for survival, $988 \mathrm{KES}$ per month per adult (GOK, 2007). Given the average adult equivalent household size was 3.3, gum arabic sales were insufficient to raise an average sized household above the rural food poverty level for even one month. In other words, the actual income generated by gum arabic for collecting households was extremely low.

Reported prices for gum arabic were comparable to prices reported in earlier research (Chiveu et al., 2008; Gachathi \& Eriksen, 20II). Although extremely low and high prices were encountered, the distribution in general was rather even, and outliers relatively uncommon. There was more variation observed in marketed quantities, as evidenced by its large standard deviation (83.3). At an average of 52.I kilograms per year per household, marketed quantities were low. Given the average quantity a collector expected to collect per day $(3.2 \mathrm{~kg})$ and the number of collectors per household (2.3), observed marketed quantities should have taken a little over a week to collect. It appears the stated importance of gum arabic for household income far exceeds the current effort exerted in its collection.

An explanation as to why gum arabic was collected at all lies not in the profitability of the activity, but rather in the timing, i.e. when gum arabic was available (Vellema,

I The calculation of adult equivalents is explained in the footnote below table 4

2 At the average exchange rate over 2009 of ro8.9 KES/Euro, this equaled Euro I9.I4. 
Mujawamariya, D'Haese, \& Burger, 2013). In Kenya, the dry season is often referred to as the 'long hunger' (Fratkin, Roth, \& Nathan, 2004). During this period, there is insufficient food available for livestock to be able to produce blood or milk, which are an important part of the diet of collecting households. Therefore, during this period households have to find another source of income to survive, namely, gum arabic collection. The safety net function of non-timber forest products is well documented across the developing world (Byron \& Arnold, I999; McSweeney, 2004). However, the minimal contribution of gum arabic to household income found in this study contrasts with earlier studies conducted on income generated by NTFPs, which usually found substantially larger contributions (Neumann \& Hirsch, 2000; Shackleton \& Shackleton, 2004). One of the reasons for the small contribution of gum in Kenya has to do with the conditions under which it was collected and the collection methods employed (Table 5).

\begin{tabular}{|c|c|c|c|c|}
\hline & Mean & SD & Min & Max \\
\hline Income from gum (KES) & $2,082.2$ & $3,534 \cdot 4$ & 42.5 & 32,000 \\
\hline Price per kg (KES) & $39 \cdot 3$ & 8.9 & IO & $67 \cdot 5$ \\
\hline Quantity (Kg/year) & 52.1 & $83 \cdot 3$ & I & 800 \\
\hline Expected quantity (kg/day) & 3.2 & 2.4 & 0.3 & 25 \\
\hline \# collectors per household & 2.3 & I.6 & $\mathrm{I}$ & 9 \\
\hline Distance to gum plots (km) & I6.0 & 10.7 & I & 45 \\
\hline Distance to gum plots (minutes) & I45.I & 98.8 & IO & 960 \\
\hline Tapping (\% yes) & $\mathrm{I} 3.8 \%$ & - & 0 & I \\
\hline Experience (years) & 6.0 & $5 \cdot 7$ & I & 25 \\
\hline Drying (\% yes) & $65.1 \%$ & - & 0 & I \\
\hline Cleaning (\% yes) & $17.0 \%$ & - & o & I \\
\hline Sorting (\% yes) & $7 \cdot 3 \%$ & - & o & I \\
\hline
\end{tabular}

Table 5: Characteristics of gum collection. Source: own data. KES = Kenyan Shilling.

Plots where gum arabic could be collected were located an average of I 6 kilometres away from the various villages included in the research. Because transport was extremely scarce, most collectors had to cover these distances on foot, which meant it took an average of three and a half hours to reach a plot. This is an impressive feat given the harsh climate; in the dry season, when gum is collected, temperatures can reach over $40^{\circ} \mathrm{C}$. Long travel times restricted the amount of time available for gum collection, the quantities that were collected as well as the control a harvester could exert over the trees gum was collected from. The long distances and the limited control might also explain why less than I $4 \%$ of interviewed collectors used tapping to increase gum yields of trees. Tapping is a technique where part of the bark of the tree is removed to stimulate gum production. It 
has been shown to improve yields of Acacia Senegal (Wekesa et al., 2009) and A Seyal varieties (Fadl, 20II). However, it requires that collectors return for the gum some time after the tree has been tapped. This potentially involves the risk of others stealing the gum, which would lower the overall return from this collection method. Another reason for low tapping rates might be limited knowledge of the technique. Only I $_{3}$ collectors, $6 \%$ of the sample, had ever received any training in tapping. Even fewer collectors used specialised tapping tools. Most tappers indicated that they had damaged trees by hitting them with a stick or using a knife (see Wekesa, Makenzi, Chikamai, Luvanda, and Muga (20I0) for a more detailed description of collection methods). It is clear collection methods were primitive, which leaves scope for improvement.

Post-harvest practices involved drying, cleaning and sorting the gum into different quality grades. Good quality gum is dry, clean gum (free of sand, dust, bark) in large nodules. Relatively simple post-harvesting practices have a large impact on the quality of gum arabic and hence the price traders are willing to pay. Of these practices, drying was the most commonly encountered, over $65 \%$ of collectors dried their gum at least once day. Of those who dried their gum, over $60 \%$ dried it directly on the ground or in a sack in front of their hut; less than half uses a dedicated drying location. By not drying the gum in a dedicated location, collectors run the risk of adulterating their gum with sand or dirt. Cleaning was observed in only $17 \%$ of the sample. This lack of cleaning is particularly problematic since most collectors collect gum that has fallen on the ground. Given that gum is a sticky material, such gum is easily adulterated by sand or plant litter. Sorting nodules by size or quality grades was very rare. Only $7 \%$ of collectors did any sorting, forcing traders to buy bulk (unsorted, unclean), and do most of the sorting themselves, which increases work and risk for the trader and reduces the price paid to collectors. Furthermore, during transport, granules of different qualities might stick together, reducing the overall quality of the load. Hence, varying qualities of gum arabic and the different relationships between traders and collectors might go a long way to explain the observed variation in prices.

\section{Traders}

Most gum was collected for marketing with only very small amounts being consumed by the households themselves. After collection, gum was stored for up to several weeks until collectors had a quantity sufficient for market (Table 6). In our sample, most collectors (75\%) sold their gum to dukas. A duka is a usually small shop selling a selection of products a household might need, such as food, tools, and clothing. For gum arabic these shops effectively function as intermediaries, storing the gum until traders or agents of traders visit the village. Various collectors also sold gum directly to these visiting agents ( $16 \%$ ) and a minority sold to wholesalers ( $7 \%$ ) or associations (3\%). Yearly marketed quantities did not differ much between collectors selling to different outlets, although collectors selling directly to agents appeared to market larger quantities on average $(76.9 \mathrm{~kg})$ than those selling to associations who achieved an average of $26 \mathrm{~kg}$. It is remarkable that collectors selling to wholesalers marketed such small quantities (4I.5 kg), 
although this low figure may be due to the small number of collectors selling to wholesalers, making the subset of observations not representative.

\begin{tabular}{l|c|c|c|c} 
Values & Duka & Agent & Wholesale & Association \\
\hline \% of respondents & $75 \%$ & $\mathrm{I} 6 \%$ & $7 \%$ & $3 \%$ \\
\hline Quantity (kg) & 46.6 & 76.9 & $4 \mathrm{I} .5$ & 26.0 \\
\hline Price (KES/kg) & 38.9 & 40.3 & 42.5 & 36.7 \\
\hline Post-harvest activities (max = 3) & 0.8 & 0.9 & $\mathrm{I} .0$ & 2.5 \\
\hline Credit (\% yes) & $28 \%$ & $9 \%$ & $0 \%$ & $17 \%$ \\
\hline Days until payment & 0.6 & 0.9 & 0.9 & 5.4
\end{tabular}

Table 6: Gum markets for collectors. Source: own data. KES = Kenyan Shilling.

Reported prices were relatively stable between outlets. Prices increased slightly with movement up the value chain from duka owners (38.9 KES) to agents (40.3 KES) to wholesale (42.5 KES). Associations paid only 36.7 KES per kilogramme of gum, the lowest average price of all outlets. Because price differences might stem from quality differences, an index summing the post-harvest activities of drying, cleaning, and sorting was made (a value of one was given if collectors performed the post-harvest activity). Higher scores should indicate more efforts in post-harvesting, and hence higher quality. If this was the case, then these quality differences did not have a substantial effect on prices. Association members had an average score of 2.5 on the quality index, but received the lowest price. For all other outlets, quality scores were similar. These uncertain returns on quality are likely to stem from a lack of knowledge regarding quality characteristics valued by the market by both collectors and traders (Mujawamariya, Burger, \& D'Haese, 2012).

Several collectors received credit from the outlet they sold gum to. Such credit was frequently received in the form of goods in exchange for repayment in the future. Because most households had limited access to cash, gum arabic and other goods often were accepted as a form of repayment. Not surprisingly, collectors selling to dukas most frequently reported receiving such credit (26\%). Associations were the second most popular outlet as providers of credit of those collectors who sold to associations $17 \%$ received credit. In societies in developing countries where formal credit institutions are absent, trust is a crucial precondition for lending in these informal credit contracts. Such trust is higher when involved parties have a long-standing relationship(Hoff \& Stiglitz, I990; Lyon, 2000), as was the case between collectors and village dukas and associations. Most collectors received cash-in-hand when selling their gum. Only association members had a waiting time of 5.4 days before receiving payment. This delay existed because associations needed to sell the purchased gum themselves before having sufficient cash to repay their members. 
The predominance of sales to non-specialised parties, the prevalence of informal interlinked transactions and the limited price obtained for quality material, strongly indicates an underdeveloped market for gum arabic. In fact, this is exactly what collectors indicated when asked to indicate the biggest problems with gum arabic marketing (Table 7). A total of $63 \%$ of collectors named the lack of a proper market their primary concern and a further $34 \%$ indicated it to be their second biggest concern. This importance of market access for increasing the income from non-timber forest products of collecting households has already been reported in other contexts (Belcher, Ruíz-Pérez, \& Achdiawan, 2005). The second most often named concern was the low price. Distance, trader reliability, transport, and lack of bargaining power were of comparatively little importance. Without a proper market for gum arabic, there is less incentive for collecting larger quantities or improving post-harvest processes.

\begin{tabular}{l|c|c} 
& Primary concern & Secondary concern \\
\hline Low price & $30 \%$ & $54 \%$ \\
\hline No proper market & $63 \%$ & $34 \%$ \\
\hline Distance & $3 \%$ & $7 \%$ \\
\hline Not dependable & $0 \%$ & $1 \%$ \\
\hline Transport & $2 \%$ & $5 \%$ \\
\hline No bargaining power & $2 \%$ & $0 \%$ \\
\hline Total & $100 \%$ & $100 \%$
\end{tabular}

Table 7: Collectors' problems in gum arabic marketing. Source: own data.

\section{Conclusion}

Kenya is richly endowed with acacia trees capable of producing gum arabic, a nontimber forest product (NTFP) which grows most abundantly in the poorest part of the country. Although the resource is abundant, Kenya exports little gum arabic; its potential to help alleviate poverty is severely underutilized. As a first step in trying to explain this apparent paradox, in this article we described the households involved in the collection of gum arabic, the role of gum in their livelihoods and the way it is collected, handled, and marketed.

Our findings show that households involved in gum arabic collection appear to be the poorest of the poorest of the poor: the poorest people in the poorest regions of a poor country. A comparison of the country's statistics on illiteracy, percentage of underweight children, income, and HDI with the same statistics for the regions where gum is collected clearly showed the relative deprivation in the gum regions. Furthermore, based on indirect measures of income it is clear that the interviewed collectors barely reached subsistence incomes. Although most collectors indicated that they mainly depended on pastoralism for their livelihoods, herds were too small to survive on. During the dry season, when there is insufficient food for livestock to produce blood and milk, households 
are pushed to the brink of starvation. During this period, gum arabic is a necessary complement to income in order to survive. Gum arabic collection does not appear to be a temporary solution: most households in our sample had several years of experience with gum collection.

The importance of gum arabic in the livelihoods of its collectors stems from the period during which it is available for collection. Actual income obtained from gum arabic collection, when looked at in terms of the total size of its contribution to annual income, was very small. Although it might have the potential to generate more income, in northern Kenya this potential was far from realised. Improvement could come from improved collection and post-harvesting techniques. Most interviewed collectors used rudimentary collection methods. Better collection techniques, such as tapping, could generate a substantial increase in quantities collected per day. Furthermore, increased use of postharvest techniques such as drying, cleaning, and sorting could increase the value of gum, creating more of an incentive to collect larger quantities. Interventions at the level of collecting households would contribute positively to both the quantity and the quality of collected gum, but might only increase incomes when collected gum is marketed.

The supply chain for gum arabic in northern Kenya is severely underdeveloped, with few dedicated traders. Most households depend on the owners of general stores, dukas, to purchase their gum. For these dukas, gum arabic is only a small part of their business and hence there is limited knowledge on proper storage methods and quality requirements. Also for the dukas, the market to which they can sell is thin. This lack of quality requirements in turn leads to small or non-existent premiums on higher quality gum, removing incentives to improve quality. Furthermore, dukas have limited resources and depend on trader visits to sell their stored gum. Because trader visits are infrequent and rare, the total amount of gum any duka can purchase is limited, reducing incentives for collectors to increase offered quantities of gum arabic. Improving the quantity and quality of collected gum arabic and consequently increasing incomes for collecting households are therefore crucially dependent on improving the supply chain. The increased availability of dedicated traders would encourage gum collection and enlarge the size of the market, increase volumes and consequently reduce transport and handling costs per unit of product. This cost reduction, combined with increased competition inherent in expanding markets, should lead to higher prices and incomes for collectors.

Interventions in the gum arabic supply chain are justified by the abominable situation most collectors are currently in. The sources of the current uncertainty regarding points of sale for collecting households go beyond the scope of this research but warrant further study, to formulate policies to effectively tackle this problem. Removing this uncertainty at the lower end of the gum arabic supply chain, would offer collecting households an alternative source of income during the most difficult period of the year, when livestock alone is insufficient to survive. As soon as a reliable market has been set up there will be a clear incentive for collectors to improve the quantity and quality of gum arabic they market. At this stage, interventions aimed at improving collection and postharvesting techniques are likely to be well-received and successful. Assisting in the de- 
velopment of the gum arabic market would provide a way for people to help themselves, which is far more sustainable than mere survival on government subsidies or food aid.

\section{APPENDIX}

\begin{tabular}{c|c} 
Number & Village name \\
\hline I & Kakilai \\
\hline 2 & Kariabur \\
\hline 3 & Loritit \\
\hline 4 & Namoroputh \\
\hline 5 & Lorengippi \\
\hline 6 & Lokiriama \\
\hline 7 & Kasuroi \\
\hline 8 & Nakukulas \\
\hline 9 & Kakongu \\
\hline I0 & Kurkum \\
\hline II & Kargi \\
\hline I2 & Ngurunit \\
\hline I3 & Laisamis \\
\hline I4 & Sereolipi \\
\hline I5 & WestGate \\
\hline I6 & Ngarendare \\
\hline I7 & ElDanaba \\
\hline I8 & Gither \\
\hline I9 & Takaba \\
\hline 20 & ShimbirFatuma \\
\hline
\end{tabular}

Table 5: Names of villages where the survey was conducted. Note: Village numbers correspond to numbers in Figure 1.

\section{References}

Anderson, D.M.W., \& Weiping, P.W. (I992). Gum Arabic (Acacia Senegal) from Uganda: Characteristics N.M.R. Spectra, Amino Compostions and Gum/Soil Cationic Relationships. International Tree Crop Journal, 7(3), pp. I67-179.

Awouda, E.H.M. (1988). The Marketing of Gum Arabic. Sudan: Gum Arabic Company.

Beentje, H.J. (1994). Kenya Trees, Shrubs and Lianas. Nairobi: National Museums of Kenya.

Belcher, B., Ruíz-Pérez, M., \& Achdiawan, R. (2005). Global patterns and trends in the use and management of commercial NTFPs: Implications for livelihoods and conservation. World Development, 33(9), pp. I435I452.

Booth, F.E.M., \& Wickens, G. E. (1988). Non-Timber Use of Selected and Zone Trees and Shrubs in Africa. Rome, Italy, Food and Agriculture Organisation. 
Brenan, J.P.M. (1983). Manual on Taxonomy of Acacia Species. Present Taxonomy of Four Species of Acacia (A. Albida, A. Senegal, A. Nilotica, A. Tortilis). Rome: Food and Agriculture Organisation of the United Nations.

Byron, N., \& Arnold, M. (1999). What Futures for the People of the Tropical Forests? World Development, 27(5), pp. $789-805$.

Chikamai, B., Hall, J.B., \& Banks, W.B. (1995). Survey of Acacia Senegal Resources for Gum Arabic in Northern Kenya. Commonwealth Forestry Review, 74(3), pp. 246-252.

Chikamai, B., \& Odera, J. A. (2002). Commercial Plant Gums and Gum Resins in Kenya: Sources of Alternative Livelihood and Economic Development in the Drylands. Nairobi: Executive Printers.

Chiveu, C.J., Dangasuk, O.G., Omunyin, M.E., \& Wachira, F.N. (2008). Genetic Diversity in Kenyan Populations of Acacia Senegal (L.) Willd. Revealed by Combined RAPD and ISSR Markers. Arfrican Journal of Biotechnoloby, 7(14), pp. 2333-2340.

Coughenour, M.B., \& Ellis, J.E. (1993). Landscape and Climatic Control of Woody Vegetation in a Dry Tropical Ecosystem: Turkana District, Kenya. Journal of Biogeography, 2o(4), pp. 383-398.

Cunningham, A.B., German, L., Paumgarten, F., Chikakula, M., Barr, C., Obidzinski, K., Puntodewo, A. (2008). Sustainable Trade and Management of Forest Products and Services in the COMESA Region: An Issue Paper. Bogor, Indonesia: Centre for International Forestry Research.

Dahl, G., \& Hort, A. (1976). Having Herds. Stockholm: University of Stockholm.

Deaton, A.S., \& Zaidi, S. (1999). Guidelines for Constructing Consumption Aggregates for Welfare Analysis: Princeton University, Woodrow Wilson School of Public and International Affairs, Research Program in Development Studies.

Dyson-Hudson, R., \& Dyson-Hudson, N. (1980). Nomadic Pastoralism. Annual Review of Anthropology, 9, pp. I5-6r.

Fagg, C.W., \& Allison, G.E. (2004). Acacia Senegal and Gum Arabic Trade (Vol. 47). Oxford: Oxford Forestry Institute.

FAO (1972). Production Yearbook 1971. Rome, Italy: Food and Agriculture Organisation of the United Nations.

Fratkin, E., Roth, E., \& Nathan, M. (2004). Pastoral Sedentarization and Its Effects on Children's Diet, Health, and Growth Among Rendille of Northern Kenya. Human Ecology, 32(5), pp. 53I-559.

Gachathi, F. N., \& Eriksen, S. (20II). Gums and resins: The potential for supporting sustainable adaptation in Kenya's drylands. Climate and Development, 3(I), pp. 59-70.

GOK (2007). Kenya Integrated Household Budget Survey 2005/06. Nairobi: Government of Kenya.

Grimm, P. (2010). Social Desirability Bias: John Wiley \& Sons, Ltd.

Gulliver, P. H. (195I). A Preliminary Survey of the Turkana: A Report Compiled for the Government of Kenya. Cape Town, South Africa: University Cape Town.

Hoff, K., \& Stiglitz, J.E. (I99o). Introduction: Imperfect information and rural credit markets: Puzzles and policy perspectives. The World Bank Economic Review, 4(3), pp. 235-250.

Houerou, H.N.L., \& Hoste, C.H. (1977). Rangeland Production and Annual Rainfall Relations in the Mediterranean Basin and in the African Sahelo-Sudanian Zone. Journal of Range Management, 30(3), pp. I8I-I89.

ICRAF (1992). A Selection of Useful Trees and Shrubs for Kenya: Notes on Their Identification, Propagation and Management for Use by Farming and Pastoral Communities. Nairobi: International Centre for Research in Agroforestry.

Islam, A.M., Phillips, G.O., Sljivo, A., Snowden, M. J., \& Williams, P. A. (I997). A review of recent developments on the regulatory, structural and functional aspects of gum arabic. Food Hydrocolloids, II(4), pp. 493-505.

ITC (2009). Gum Arabic - MNS June 2009 Market News Service (MNS): International Trade Centre.

Lewis, I. M. (1999). A pastoral democracy: A study of pastoralism \& politics among the northern Somali of the horn of Africa: James Currey Publishers. 
Lind, J. (2005). Relief Assistance at the Margins: meanings and perceptions of dependency in Northern Kenya.

Lyon, F. (2000). Trust, networks and norms: The creation of social capital in agricultural economies in Ghana. World Development, 28(4), pp. 663-68r.

Maundu, P.M., Ngugu, G.W., \& Kasuye, H.C. (1999). Traditional Food Plants of Kenya. Nairobi, Kenya: National Museums of Kenya.

McSweeney, K. (2004). Forest Product Sale as Natural Insurance: The Effects of Household Characteristics and the Nature of Shock in Eastern Honduras. Society \& Natural Resources, I7(I), pp. 39-56.

Mujawamariya, G., Burger, K., \& D'Haese, M. (2012). Quality of gum arabic in Senegal: Linking the laboratory research to the field assessment. Quarterly Journal of International Agriculture, 5I(4), pp. 357-383.

Neumann, R.P., \& Hirsch, E. (2000). Commercialisation of non-timber forest products: review and analysis of research. Bogor, Indonesia: CIFOR.

Nishinari, K., \& Doi, E. (Eds.). (1993). Food Hydrocolloids: Structures, Properties and Functions. Springer.

Olang, M.O. (1984). Vegetation Cover Assessment in Turkana District, Kenya. International Institute for Land Reclamation and Improvement, Wageningen, The Netherlands, pp. 183-194.

Pratt, D.J., \& Gwynne, M.D. (1977). Rangeland management and ecology in East Africa. London: Hodder and Stoughton.

Raddad, E., Salih, A., Fadl, M., Kaarakka, V., \& Luukkanen, O. (2005). Symbiotic nitrogen fixation in eight Acacia senegal provenances in dryland clays of the Blue Nile Sudan estimated by the natural abundance method. Plant and Soil, 275(I), pp. 26r-269.

Roth, E., \& Fratkin, E. (2005). The Social, Health and Economic Consequences of Pastoral Sedentarisation in Marsabit District, Northern Kenya. In E. Fratkin \& E. Roth (Eds.), As Pastoralists Settle, Springer, p. 280.

Scoones, I. (1998). Sustainable rural livelihoods: A framework for analysis IDS. Working paper (Vol. 72): Institute of Development Studies.

Shackleton, C.M., \& Shackleton, S.E. (2004). The Importance of Non-Timber Forest Products in Rural Livelihood Security and As Safety Nets: A Review of Evidence From South-Africa. South African Journal of Science, roo, pp. $658-664$.

Smith, K. (2005). From Milk to Maize: As Pastoralists Settle. In E. Fratkin \& E. A. Roth (Eds.), United States: Springer US, pp. I37-I53.

Spencer, P. (1973). Nomads in Alliance: Symbiosis and Growth among the Rendille and Samburu of Kenya. London: Oxford University Press.

Spencer, P. (2004). The Samburu: a Study of Gerontocracy in a Nomadic Tribe. London: Reprinted by Routledge.

Timko, J.A., Waeber, P. O., \& Kozak, R. A. (2010). The Socio-Economic Contribution of Non-Timber Forest Products to Rural Livelihoods in Sub-Saharan Africa: Knowledge Gaps and New Directions. International Forestry Review, I2(3), pp. 284-294.

Van Dalen, D. (2006). Arabische gom. Amsterdam: Bert Bakker.

Vellema, W., Mujawamariya, G., D'Haese, M., \& Burger, K. (2013). An economic approach to household collection of gum arabic from the wild. International Forestry Review, 15(2), pp. 255-269.

Webb, J.L.A. (1985). The Trade in Gum Arabic: Prelude to French Conquest in Senegal. The Journal of African History, 26(2), pp. I49-168.

Wekesa, C., Makenzi, P.M., Chikamai, B. N., Luvanda, A.M., \& Muga, M.O. (2010). Traditional Ecological Knowledge Associated with Acacia senegal (Gum Arabic Tree) Management and Gum Arabic Production in Northern Kenya. International Forestry Review, I2(3), pp. 240-246.

Whistler, R.L., \& BeMiller, J.N. (1993). Industrial Gums (3rd ed.). San Diego, CA: Academic Press.

White, F. (1983). The Vegetation of Africa. Paris: UNESCO.

Woldeamanuel, T., Arts, B., Lemenih, M., \& Bongers, F. (201I). Dryland Resources, Livelihoods and Institutions: Diversity and Dynamics in Use and Management of Gum and Resin Trees in Ethiopia. (PhD), Wageningen University, Wageningen. 
